University of Wollongong

Research Online

Faculty of Law, Humanities and the Arts Papers (Archive)

Faculty of Arts, Social Sciences \& Humanities

$1-1-2014$

Southeast Asia's maritime piracy: challenges, legal instruments and a way forward

Ahmad Amri

University of Wollongong, aaa799@uowmail.edu.au

Follow this and additional works at: https://ro.uow.edu.au/lhapapers

Part of the Arts and Humanities Commons, and the Law Commons

Research Online is the open access institutional repository for the University of Wollongong. For further information contact the UOW Library: research-pubs@uow.edu.au 


\title{
Southeast Asia's maritime piracy: challenges, legal instruments and a way forward
}

\begin{abstract}
Piracy is considered a critical maritime security threat in Southeast Asia. Whilst piracy has always been a perennial problem in the region, this threat has received increasing attention over the past few years. Reports published by the International Maritime Organization as well as the International Maritime Bureau show an alarming increase in acts of piracy on Southeast Asian waters over the past decade. In ancient times, the main drivers of piracy were raiding for plunder and capture of slaves; however, in modern times, developments in politics, economics and even military technology have drastically altered the universal crime of piracy. There are a variety of motives behind modern day piracy including economic gains from receiving ransoms from governments or shipping companies, political and even terrorist reasons.

However, it cannot be denied that piratical attacks persist and continue. Efforts are being taken by States at the international as well as regional level to combat piracy. At the international level, piracy is addressed in several legal frameworks. The primary legal framework is contained in the 1982 United Nations Convention on the Law of the Sea, which allows Member States to address piracy in their national legislation. At the regional level, measures taken in order to fight piracy include the adoption of the ASEAN Declaration on the Prevention and Control of Transnational Crime, which includes piracy as a transnational crime. This paper will examine the adequacy of legal frameworks at both the international and regional levels in order to address the current legal measures for combating piracy. Furthermore, it will discuss current challenges in the implementation of anti-piracy measures at the international and regional levels.
\end{abstract}

\section{Keywords}

maritime, asia, forward, southeast, way, instruments, legal, challenges, piracy

\section{Disciplines}

Arts and Humanities | Law

\section{Publication Details}

A. Amri, 'Southeast Asia's maritime piracy: challenges, legal instruments and a way forward' (2014) 6 (3) Australian Journal of Maritime and Ocean Affairs 154-169. 


\title{
Southeast Asia's Maritime Piracy: Challenges, Legal Instruments and Way Forward*
}

\author{
Ahmad Almaududy Amri \\ PhD Candidate, Australian National Centre for Ocean Resources and Security (ANCORS) \\ University of Wollongong, NSW, Australia
}

\begin{abstract}
Piracy is considered a critical maritime security threat in Southeast Asia. Whilst piracy has always been a perennial problem in the region, this threat has received increasing attention in the region over the past few years. Reports published by the International Maritime Organisation as well as the International Maritime Bureau show an alarming increase in acts of piracy on Southeast Asian waters over the past decade. In ancients times, the main drivers of piracy were raiding for plunder and capture of slaves; however, in modern times, developments in politics, economics and even military technology have drastically altered the universal crime of piracy. There are a variety of motives behind modern day piracy including economic gains from receiving ransoms from government or ship companies, political and even terrorist reasons. However, it cannot be denied that piratical attacks persist and continue. Nonetheless, there are efforts being taken by states at the international as well as regional level to combat piracy. At the international level, piracy is addressed in several legal frameworks. The primary legal framework is contained in the 1982 United Nations Convention on the Law of the Sea, which allows member states to address piracy in their national legislation. At the regional level, measures taken in order to fight piracy include the adoption of the ASEAN Declaration on the Prevention and Control of Transnational Crime, which includes piracy as a transnational crime. This paper will examine the adequacy of legal frameworks at both the international and regional levels in order address the current legal measures in combating piracy. Furthermore, it will discuss current challenges in the implementation of anti-piracy measures at the international and regional levels.
\end{abstract}

Keywords (five keywords)

Piracy, Southeast Asia, Maritime Security, Legal Frameworks and Challenges.

* This is an update and revised version of a paper presented in $5^{\text {th }}$ International Conference on Southeast Asia, Malaysia 2013 


\section{Introduction}

One of the main threats to maritime security in Southeast Asia is piracy. Indeed, in the past few years, this threat has gained the attention of both the International Maritime Organisation (IMO) and the International Maritime Bureau (IMB) - with both organisations referring to piracy in Southeast Asia in their published reports.

The IMO and IMB are the two main organisations which are concerned with the issue of piracy. Both organisations have defined piracy in different ways. The IMO, as a body under the UN, adopts the definition of piracy from the UNCLOS ${ }^{1}$. The definition itself is quite narrow and defines some illegal activities at sea to be 'piracy'. The IMB, on the other hand, is a part of the International Chamber of Commerce (ICC) which more or less has the same agenda. Compared to the IMO, the IMB's definition is broader and covers almost all attacks against ships in all maritime jurisdictions of a state.

Theoretically, acts of piracy should be reported to either the IMO or the IMB so that interested parties can be alerted to those maritime areas that are prone to piracy. Reporting also allows states and companies to take preventive steps in respect of their maritime operations. However, shipping companies and vessel crews are sometimes reluctant to report acts of piracy to international and local authorities. Several reasons have been cited for this reluctance, including the complexity of reporting procedures and a distrust of local authorities which have carriage of piracy cases.

Although piracy attacks continue to occur, with an increase in the number of executions perpetrated by pirates, states are taking action at both the international and regional level. At the international level, anti-piracy measures have been addressed by international conventions. The 1982 UNCLOS gave each state the right to govern piracy under their national legislation. As a result, states have the power to investigate, capture, prosecute and punish pirates pursuant to their domestic legislation, especially where the illegal acts have been committed within the state's maritime jurisdiction ${ }^{2}$.

At the regional level, measures have been taken by groups of states to fight piracy. In the Caribbean for instance, the Netherlands, France, the US, England, Jamaica and Venezuela have worked together to combat drug trafficking and piracy. Another regional effort is the joint patrol between Japan, India and Malaysia, which was implemented as a result of the anti-piracy conference in Japan in $2000^{3}$. However, regional efforts are not always successful. In the South China Sea, for example, limited funds, sovereignty disputes, overlapping maritime jurisdictions and a lack of extradition procedures has made the implementation of a regional mechanism very difficult ${ }^{4}$.

\section{Nature of Piracy in Southeast Asia}

Southeast Asia is considered as an area which is important in terms of piratical studies. There are several reasons to this argument: Firstly, It has the second highest figure of piracy

\footnotetext{
${ }^{1}$ D. Johnson, E. Pladder and M Valencia, J., 'Introduction: Research on Southeast Asian Piracy' in D. Johnson, E. Pladdet and M Valencia, J. (eds), Piracy in Southeast Asia: Status, Issues, and Responses (ISEAS, 2005)

${ }^{2}$ K. Zou, 'Enforcing the Law of Piracy in the South China Sea' (2000) 31 Journal of Maritime Law and Commerce

${ }^{3}$ Johnson, Pladder and Valencia, above n 1

${ }^{4}$ Zou, above n 2
} 
attacks in the world from 2008-2012. Only the African Region transcends the number of piracies that were committed in Southeast Asia. The significance of the African statistic is due to the significant cases that occurred in the Somalian water.

In 2013 the number of reported piracy incidents by the Singaporean-managed vessels was the highest worldwide 5 . There were 79 cases reported and this number is more than twice the piracy reported incident by Germany owned vessels (34 incidents). Furthermore it was also reported that attacks towards ships which are registered in Singapore is the second highest in the world after Liberia. According to Choong, the head of Piracy Reporting Centre of IMB that Singaporean-managed or registered ships are not the primary targets of the piracy attacks. There are cases where master of the ship are not active enough in reporting attacks to their ships. Choong also noted that in general counter piracy measures have some effect in declining the number of piracies, however he is concerned on those attacks which are not reported to piracy reporting centres ${ }^{6}$.

According to the data from the IMB, piracies both as 'actual' or attempted' in the Southeast Asian water in the last five years reached its peak in 2010 which accounted 113 number of piracies. 2010 onwards, the number of attacks remained stable, although there were slight reduction in 2011 and 2012. From the table below, it is also clear that Indonesia, Malaysia, Vietnam and Singapore were the states which highly affected by piracy between the period of 2008 to 2012.

Acts of Piracy and Armed Robbery against Ships which were reported to have been Allegedly Committed and Attempted in Southeast Asia and Far East (excluding China) ${ }^{7}$

\begin{tabular}{|c|c|c|c|c|c|}
\hline Locations & 2008 & 2009 & 2010 & 2011 & 2012 \\
\hline \multicolumn{6}{|l|}{ Southeast Asia } \\
\hline Indonesia & 28 & 15 & 40 & 46 & 81 \\
\hline Malacca Strait & 2 & 2 & 2 & 1 & 2 \\
\hline Malaysia & 10 & 16 & 18 & 16 & 12 \\
\hline Myanmar & 1 & 1 & 0 & 1 & 0 \\
\hline Philippines & 7 & 1 & 5 & 5 & 3 \\
\hline Singapore Straits & 6 & 9 & 3 & 11 & 6 \\
\hline Thailand & 0 & 2 & 2 & 0 & 0 \\
\hline \multicolumn{6}{|l|}{$\begin{array}{l}\text { Far East } \\
\text { (excluding China) }\end{array}$} \\
\hline South China Sea & 0 & 13 & 31 & 13 & 2 \\
\hline Vietnam & 11 & 9 & 12 & 8 & 4 \\
\hline & 65 & 68 & 113 & 101 & 110 \\
\hline
\end{tabular}

Secondly, the geographical location of the region is very important to world trade. There are several sea lanes and straits which are normally used for international navigation mainly for trade purposes. In fact, there are six out of 25 busiest ports all over the world located in Southeast Asia, namely: Tanjung Priok (Indonesia), Tanjung Pelepas (Malaysia), Port Kelang (Malaysia), Singapore, Manila (Philippines) and Laem Chabang (Thailand) ${ }^{8}$.

\footnotetext{
5 Today, Safer Waters: Global Piracy Menance on the Wane (27 March 2014)

<http://www.todayonline.com/sites/default/files/manualassets/pirates_2014/index.html>access date 1 April 2014

${ }^{6}$ Ibid

${ }^{7}$ ICC IMB 2012 Annual Report on Piracy and Armed Robbery against Ships

${ }^{8}$ T. Shie, 'Maritime Piracy in Southeast Asia: The Evolution and Progress of Intra-ASEAN Cooperation' in G.

Gerard and O. Webb (eds), Piracy, Maritime Terrorism and Securing the Malacca Straits (ISEAS Publishibg, 22
} 
Thirdly, the concern of eradicating the piracy problem has been an issue for a state and also group of states ${ }^{9}$. Their failure in addressing the issue has awakened the international community to cooperate in supressing piracy occurring in Southeast Asian waters.

Piracy at the Southeast Asian waters is affected by numerous factors such as modern economy, politic and social forces. These factors along with the increase of the widespread of information and the growing of globalization influenced the modern world as well as Piracy ${ }^{10}$.

Piracy in Southeast Asia region is problematic to define as it differs from piracy at the other parts of the world. As described by Young, it has its own 'religious, economic and political agendas' ${ }^{11}$. However, these understanding changed after the European involvement in the region in the $16^{\text {th }}$ century during the imperialism and colonialism period. The local concept of piracy vanished and was replaced by the European concept. By the nineteenth century European concepts were officially imposed to most countries in Southeast Asia ${ }^{12}$. This is also the reason why the European concept today also used as the formal international concept.

In the past, most of the efforts that were identified by researchers were conducted by actors or states outside Southeast Asia. Japan and United States as well as other shipping nations have been concerned about the situation in the region and hence offered anti-piracy measures ${ }^{13}$.

\section{Targeted Ships in Southeast Asian Piracy}

In most of its operation, the pirates often target vessels which are berthed in ports or at anchor position ${ }^{14}$. These actions are usually conducted in Vietnam, Philippines as well as Indonesia. In responding this problem, authorities especially the marine police conduct patrolling around the port areas ${ }^{15}$.

Attacks are also conducted when ships are sailing ${ }^{16}$. These attacks are more organised and more difficult to conduct. These ships are targeted because of their position which is not close to the shore and crews are busy doing their responsibilities on board, hence pirates are able to approach the ship by using small vessel without being noticed. The motive of this operation is to steal valuables and cash on board. These attacks rarely involve violence. Only on several occasions where there are confrontations with the crews then violence is conducted by the pirates. The prominent example to illustrate these actions is attacks conducted in 2010 in Indonesia (near Anambas and Natuna islands) and in southern South China Sea near Pulau Tioman $^{17}$.

Another type of ships which are attacked is tugs and barges ${ }^{18}$. These ships are usually hijacked then repainted and renamed to be sold. This operation is well organised and there is a risk of being caught if they are unsuccessful, hence in order to conduct such attack offenders required to plan their actions cautiously ${ }^{19}$.

\footnotetext{
${ }^{9}$ Ibid

${ }^{10}$ AJ Young, 'Roots of Contemporary Maritime Piracy in Southeast Asia' in D. Johnson and M. Valencia (eds), Piracy in Southeast Asia: Status, Issues, and Responses (ISEAS Publications, 2005) 3322

${ }^{11}$ Ibid

${ }^{12}$ Ibid

${ }^{13}$ Shie, above $\mathrm{n} 8$

${ }^{14}$ ASPI, 'Special Report: Calming Troubled Waters: Global and Regional Strategies for Countering Piracy '

(Australian Strategic Policy Institute, 2012)

${ }^{15}$ Ibid

${ }^{16}$ Ibid

${ }^{17}$ Ibid

${ }^{18}$ Ibid

${ }^{19}$ Ibid
} 


\section{The difference between Southeast Asia and Somalian Piracy}

The counter piracy measures in Southeast Asia are considered more successful than those measures implemented in some other parts of the world ${ }^{20}$. Piracy conducted in Somalia for instance, such piracy is of different model and apparently it is unlikely to occur in Southeast Asia because of several reasons: firstly, the offenders in the Somali Piracy are often able to escape without being punished as there is no effective policy applicable to punish the pirates. Furthermore, knowing that the political instability in the country is still prevailing, it is quite difficult for the authorities to enforce the law ${ }^{21}$.

Secondly, the geographical difference between the two areas is another reason why Somali piracies cannot occur in Southeast $\mathrm{Asia}^{22}$. The Somalian waters are widely open where as in the case of Southeast Asia, the water areas are relatively narrow. Therefore Somali piracies involve Mother Ships in the actions which support the small vessels in conducting their attack. Southeast Asia pirates usually conducts the hit and run attack. This form of an attack is unsuitable for Somalian piracies ${ }^{23}$.

The third reason is the modus operandi of the attack in both areas. The Somalian piracy are well organised often takes place during day time with the use of various weapons in order to threaten the crew members ${ }^{24}$. On the other hand, piracy offenders in Southeast Asia conduct its action in night time where they usually steal valuable which are present on the ship. These attacks are less organised and the offenders seldom use firearms in their actions. Knives and machetes are the common weapon used by them ${ }^{25}$.

\section{Overview of the International Legal Framework on Piracy}

\section{IMO and IMB}

IMO and IMB have defined piracy in different ways. IMO as a body under the UN adopts the definition of piracy from UNCLOS ${ }^{26}$. On the other hand, IMB has also defined the act of piracy. Compared to IMO, IMB's definition is broader and almost covers all attacks against ship in all maritime jurisdictions of a state. IMB explained piracy in three different elements: first, there should be an act committed by the crew or the passenger of the ship to board or attempting to board any ship; second, the motive of this act is to commit theft or any other crime; finally, there should be 'an attempt or capability to use force in furtherance of that act ${ }^{27}$.

It is clear that IMB defined piracy broader than IMO. Requirement such as the act should be committed only at high seas in order to be categorized as piracy is waived by IMB. Furthermore, the involvement of two ships in its conduct is also ignored by the IMB's definition which allows the attack from raft and quays as part of piracy. In addition, there is no limitation that an act should be committed for private ends, hence if the motive of the criminal act is

\footnotetext{
${ }^{20}$ Ibid

${ }^{21}$ Ibid

${ }^{22}$ Ibid

${ }^{23}$ Ibid

${ }^{24}$ Ibid

${ }^{25}$ Today, above $\mathrm{n} 5$

${ }^{26}$ Johnson, Pladder and Valencia, above $\mathrm{n} 1$

${ }^{27}$ J. Abhyankar, An Overview on Piracy Problems-A Global Update <http://www.sils.org/sminar/1999-piracy00.htm>
} 
political or regarded to have environmental motives will still be categorized as piracy ${ }^{28}$. Therefore, the attack against Achille Lauro according to IMB's definition regarded as an act of piracy $^{29}$. Interestingly, actions committed by the naval ships which most of the time are under the state's agenda, if can be proved to commit criminal act, can also be categorized as piracy under the definition of IMB.

\section{Statistics of IMO}

From the reports published by IMO it is clear that there were major increase in the piratical act in the Malacca Strait and South China Sea for both attempted and committed from 2009 to 2010. Between the 5 years period (2008-2012), year 2010 showed the significance of illegal acts (piracy and armed robbery) in Southeast Asia as 2010 marked the peak of the number of attacks between those periods and accounts as the starting year where the number of attacks in the region remains high.

In terms of location where the illegal act took place, the figure showed variations. In 2008, 2010 and 2011, the number of piracies occurring in international waters was higher than in territorial sea, whereas in 2009 and 2012 the number of illegal acts occurring in territorial sea was higher than in international waters. The IMO also reported that there were several attacks in ports that lies in the Malacca Strait and South China Sea.

Acts of Piracy and Armed Robbery against Ships which were reported to have been Allegedly Attempted in Malacca Strait and South China Sea $^{30}$

\begin{tabular}{|l|c|c|c|c|c|}
\hline & $\mathbf{2 0 0 8}$ & $\mathbf{2 0 0 9}$ & $\mathbf{2 0 1 0}$ & $\mathbf{2 0 1 1}$ & $\mathbf{2 0 1 2}$ \\
\hline Location of Incident & 9 & 5 & 17 & 7 & 0 \\
\hline $\begin{array}{l}\text { In International } \\
\text { Waters }\end{array}$ & 2 & 8 & 5 & 3 & 3 \\
\hline In Territorial Waters & 1 & 1 & 3 & 2 & 4 \\
\hline In port area & $\mathbf{1 2}$ & $\mathbf{2 5}$ & $\mathbf{1 2}$ & $\mathbf{7}$ \\
\hline & $\begin{array}{l}\text { Status of Ship when } \\
\text { Attacked }\end{array}$ \\
\hline Steaming & 10 & 8 & 20 & 10 & 1 \\
\hline At anchor & 2 & 5 & 4 & 2 & 6 \\
\hline Not Stated & 0 & 1 & 1 & 0 & 0 \\
\hline
\end{tabular}

Acts of Piracy and Armed Robbery against Ships which were reported to have been Allegedly Committed in Malacca Strait and South China Sea ${ }^{31}$

\footnotetext{
${ }^{28}$ Johnson, Pladder and Valencia, above n 1

${ }^{29}$ Ibid

${ }^{30}$ IMO Annual Reports (2008-2012) on Acts of Piracy and Armed Robbery against Ships.
}

In 2009 and 2010 no column for Malacca Strait but there was a column in 2008 and reappears in 2011, the writer assumes that there were no incidents according to the IMO report during those years. However, IMB's reports show a small number of piracy attacks in 2009 and 2012. 


\begin{tabular}{|c|c|c|c|c|c|}
\hline & 2008 & 2009 & 2010 & 2011 & 2012 \\
\hline \multicolumn{6}{|l|}{ Location of Incident } \\
\hline In Territorial Waters & 18 & 20 & 33 & 23 & 14 \\
\hline In International Waters & 30 & 27 & 38 & 54 & 24 \\
\hline \multirow[t]{2}{*}{ In port area } & 14 & 10 & 38 & 46 & 69 \\
\hline & 62 & 57 & 109 & 123 & 107 \\
\hline \multicolumn{6}{|l|}{$\begin{array}{l}\text { Status of Ship when } \\
\text { Attacked }\end{array}$} \\
\hline Steaming & 21 & 23 & 40 & 42 & 25 \\
\hline At anchor & 31 & 31 & 50 & 66 & 76 \\
\hline Not Stated & 10 & 3 & 19 & 15 & 6 \\
\hline
\end{tabular}

\section{Statistics of IMB}

Statistics have shown that the number of piracy attacks increased from 2008 onwards and reached its peak in 2010. IMB Piracy Reporting Centre (PRC) reported that in 2010 there were 445 piracy attacks. The attacks were of different kinds such as attack in ports, stealing of valuable belongings of crew members and ship equipment as well as hijacking of ships. IMB PRC reported that there were 196 ships boarded, 53 hijacked, 1174 crew hostages, 8 crews were killed, 37 injured and there were 27 crews kidnapped ${ }^{32}$. The figure however slightly decreased in 2011 where there were 439 attacks (176 ships boarded, 45 hijacked, 802 crew hostages, 8 killed, 42 injured and 10 people were kidnapped). 2012 showed a different pattern. There was a dramatic fall in the number of piratical attacks. Nonetheless, the number of attacks was still high reaching 297 which were slightly higher than the number of attack in 2008.

Comparison of the Type of Attacks, January-December 2008-2012 ${ }^{33}$

\begin{tabular}{|l|c|c|c|c|c|}
\hline Category & $\mathbf{2 0 0 8}$ & $\mathbf{2 0 0 9}$ & $\mathbf{2 0 1 0}$ & $\mathbf{2 0 1 1}$ & $\mathbf{2 0 1 2}$ \\
\hline Attempted & 47 & 85 & 89 & 105 & 67 \\
\hline Boarded & 151 & 155 & 196 & 176 & 174 \\
\hline Fire upon & 46 & 121 & 107 & 113 & 28 \\
\hline Hijack & 49 & 49 & 53 & 45 & 28 \\
\hline Total & 293 & 410 & 445 & 439 & 297 \\
\hline
\end{tabular}

Types of Violence to Crew, January-December 2008-2012

\footnotetext{
31 Ibid.

${ }^{32}$ P. Mukundan, 'The Scourage of Piracy in Southeast asia: Can Any Improvements be Expected in the Near Future?' in D. Pladder Johnson, E. Valencia, M, J. (ed), Piracy in Southeast Asia: Status, Issues, and Responses (ISEAS, 2005)

${ }^{33}$ ICC IMB 2012 Annual Report on Piracy and Armed Robbery against Ships

${ }^{34}$ Ibid.
} 


\begin{tabular}{|l|c|c|c|c|c|}
\hline Types of Violence & $\mathbf{2 0 0 8}$ & $\mathbf{2 0 0 9}$ & $\mathbf{2 0 1 0}$ & $\mathbf{2 0 1 1}$ & $\mathbf{2 0 1 2}$ \\
\hline Assaulted & 7 & 4 & 6 & 6 & 4 \\
\hline Hostage & 889 & 1050 & 1174 & 802 & 585 \\
\hline Injured & 32 & 69 & 37 & 42 & 28 \\
\hline Kidnaped/Ransom & 42 & 12 & 27 & 10 & 26 \\
\hline Killed & 11 & 10 & 8 & 8 & 6 \\
\hline Missing & 21 & 8 & - & - & - \\
\hline Threatened & 9 & 14 & 18 & 27 & 13 \\
\hline Total & 1011 & 1167 & 1270 & 895 & 662 \\
\hline
\end{tabular}

The decrease in number however does not affect the percentage of the piratical act committed in Southeast Asian waters. In 2012 Southeast Asia and Far East (excluding China) together, accounts the second highest region affected by piracy. There were 110 out of 297 attacks which originated from these regions. Only Africa transcends the number of piratical attacks in Southeast Asia with 150 attacks. There was significant increase from 2009 to 2010, from 2010 the trends remains plateau with slight decrease until the end of 2012.

Total Incidents per Region, January-December $2012^{35}$

\begin{tabular}{|l|c|}
\hline Region & Number of Attack \\
\hline Far East & 7 \\
\hline America & 17 \\
\hline Indian Sub-Continent & 19 \\
\hline Southeast Asia & 104 \\
\hline Africa & 150 \\
\hline
\end{tabular}

\section{United Nation Convention on Law of the Sea}

The Security Council has repeatedly reaffirmed that "international law, as reflected in UNCLOS, regulates the legal framework applicable to combating piracy and armed robbery at sea, as well as other ocean activities". The United Nations in particular has regulated the problems of piracy in articles 100 to 107. Article 100 of UNCLOS has defined piracy as an illegal act "on the high seas or in any other place outside the jurisdiction of any state" and also obliges "all states to cooperate to the fullest possible extent in the repression of piracy".

UNCLOS has defined piracy in article 101 which consists of 5 elements. The definition itself is quite narrow and restricts some illegal activities at sea to be defined as piracy. An act can only be categorised as piracy if it comprises: First, there should be a violence, detention or depredation committed; second, it should be conducted on high seas, hence states do not have neither sovereignty nor sovereign rights over the maritime area; third, there should be two ships involved in the action, therefore there should be another ship used by the pirates in order to attack the targeted ship. Illegal acts such as mutiny and privateering are not categorized as piracy; fourth, piracy should be conducted on behalf of private sector. The economic gain from successfully pirated ships will be enjoyed by private ends; fifth, the vessels used to conduct

\footnotetext{
${ }^{35}$ Ibid.
} 
piracy should be a private vessel ${ }^{36}$. Hence, attack by government owned ships such as naval ships is not considered as the act of piracy.

Recalling this definition by UNCLOS, many illegal acts at sea have been excluded by it. Criminal act conducted in territorial sea where states have sovereignty and jurisdiction over it, is not categorized as piracy. This act is considered by UNCLOS as arms robbery at sea. This provision gave birth to the other sort of problems. As not every state has domestic regulation against arms robbery, it is quite complicated for governments to handle the illegal act when arms robbery is conducted. Only those acts which is committed on high seas where states enjoy the freedom of navigation or 'mare liberum', is considered as piracy.

In article 103, UNCLOS has defined a pirate ship or aircraft. UNCLOS briefly explains that if a ship or an aircraft is under a dominant control of a person who intends to commit one of the acts stipulated in article 101, then it is considered as pirate ship or aircraft. Furthermore, the same provision applies for those ships and aircrafts which have been used to conduct piracy which is still under the control of the pirate who committed the act.

Warships, government ships and government aircrafts are treated the same as private ships if it commits acts mentioned in article 101 as a result of mutiny and taken control of the ship or aircraft ${ }^{37}$. This provision is stipulated in article 102 of the UNCLOS. In any cases if a crew in a warship or a government ship or aircraft rebels and takes over the ship or aircraft, then conducts an act of piracy, this activity is considered illegal and included as piracy.

Over a pirate ship or aircraft, UNCLOS has regulated that a flag state may retain or lose the ownership of the ship or aircraft which is determined by the domestic law of the flag state. If a state under its national law regulated that pirate ship which is registered under their national shall retain ownership, then according to UNCLOS article 104, the state has the right to own the pirate $\operatorname{ship}^{38}$.

Seizure over pirate ship or aircraft is permissible according to UNCLOS (article 105) under a certain circumstance. The seizure should take place on high seas or other place outside the jurisdiction of any state. The state which conducts the seizure is given the right to arrest the pirate and seize the property on the ship or aircraft. The state through its courts has the right to impose sanctions towards the pirates as well as take appropriate actions over the property on board.

Article 107 UNCLOS determines the ships or aircrafts which has the authority to conduct such seizure. Warships, military aircrafts as well as other ships or aircraft which are authorized by the government and has a sign or mark which is clearly identifiable as government service ship or aircraft are those permitted by UNCLOS.

Seizure over pirated ships is not always lawful. Seizure which is conducted by a state without adequate ground shall be subject to provision stipulated in article 106. State which conducts such acts shall be liable to any loss or damaged of the ship or aircraft to the flag state of the seized ship or aircraft ${ }^{39}$.

\section{Convention on the Suppression of Unlawful Act against the Safety of Navigation}

\footnotetext{
${ }^{36}$ Johnson, Pladder and Valencia, above n 3

${ }^{37}$ S. Kaye, 'The International Legal Framework for Piracy' in A. Forbes (ed), Australia's Response to Piracy: A Legal Perspective (National Library of Australia, 2011) vol 31, 10

${ }^{38}$ Ibid

${ }^{39}$ Ibid
} 
SUA Convention is one of the legal instruments used to combat against illegal acts conducted at sea including piracy. This convention does not specifically aim to address piracy, however, piratical acts is subject to SUA Convention. This convention was initiated after the hijacking of an Italian cruise ship, Achille Lauro in 1988 which was allegedly motivated by political ends ${ }^{40}$. Unfortunately, article 101 UNCLOS was not able to punish the perpetrators as the act did not meet the requirement 'committed for private end'. Therefore states find it important to create a legally binding instrument which could arrest criminal acts at sea committed for political and other ends.

This convention filled the gap in UNCLOS that limits illegal acts of piracy which requires the two ships involvement as well as it should occur on high seas or other areas beyond the national jurisdiction ${ }^{41}$. According to article 3 SUA Convention, it is against the convention if any person unlawfully and intentionally: a. to seize or exercise control over that ship by force, threat, or intimidation; b. perform an act of violence against a person on board a ship if that act is likely to endanger the safe navigation of the ship; c. destroy or cause damage to a ship or its cargo which is likely to endanger the safe navigation of the ship; d. places or causes to be places on a ship a device which cause damage to the ship or its cargo; e. destroys maritime navigational facilities; f. communicates false information; and g. injures or kills any person in connection with the commission point a to $\mathrm{f}$.

As mentioned above, unlike UNCLOS that an offender according to SUA Convention does not require two ship involvement as well as committed on high seas. By taking over the control of a ship with the use of force or intimidation alone can be classified as an offence against this convention even though the perpetrator is from the same ship. Furthermore, to accuse a person as an offender against this convention, a state does not need to acquire the high seas requirement, article 4 explained that SUA Convention 'applies if the ship is navigating of is scheduled to navigate into, through or from waters beyond the outer limit of the territorial sea'.

SUA Convention also aims to punish its offenders. Article 10 (1) expounded that a state is responsible to prosecute or extradite the offenders committing one or more of the crime stated in article 3 of this convention ${ }^{42}$. Article 11(1) elaborated that offences in article 3 are extraditable based on the extradition treaty between states. On those scenarios where states do not have treaties of extradition, this convention through article 11 (2) allows states to use the SUA Convention as the legal basis of extradition. In terms of prosecution the convention clearly reveals in article 6 (1) that state party has the right to establish jurisdiction if the offence meets one of these aspects: a. if the offence is against or on board a ship flying the flag of a state; $b$. if the attack is committed in the territorial sea as well as territory of the state; and c. if the perpetrator is a citizen of the state.

\section{Accession Status of International Conventions in Southeast Asia ${ }^{43}$}

\footnotetext{
${ }^{40} \mathrm{~J}$. Harrelson, 'Blackbeard meets blackwater: An analysis of international conventions that address piracy and the use of private security companies to protect the shipping industry' (2010) $25 \mathrm{Am}$. U. Int'l L. Rev. 313

${ }^{41}$ Ibid

${ }^{42}$ Ibid

${ }^{43} \mathrm{http} / / / \mathrm{www}$. imo.org/About/Conventions/StatusOfConventions/Pages/Default.aspx
} 


\begin{tabular}{|l|c|c|c|c|}
\hline & $\begin{array}{c}\text { SUA Convention } \\
1988\end{array}$ & SUA Protocol 1988 & $\begin{array}{c}\text { SUA Convention } \\
2005\end{array}$ & SUA Protocol 2005 \\
\hline Brunei Darussalam & $\sqrt{ }$ & $\sqrt{ }$ & $\mathrm{x}$ & $\mathrm{x}$ \\
\hline Cambodia & $\sqrt{ }$ & $\sqrt{ }$ & $\mathrm{x}$ & $\mathrm{x}$ \\
\hline Indonesia & $\mathrm{x}$ & $\sqrt{ }$ & $\mathrm{x}$ & $\mathrm{x}$ \\
\hline Laos & $\sqrt{ }$ & $\mathrm{x}$ & $\mathrm{x}$ & $\mathrm{x}$ \\
\hline Malaysia & $\mathrm{x}$ & $\sqrt{ }$ & $\mathrm{x}$ & $\mathrm{x}$ \\
\hline Myanmar & $\sqrt{ }$ & $\mathrm{x}$ & $\mathrm{x}$ & $\mathrm{x}$ \\
\hline Philippines & $\sqrt{ }$ & $\mathrm{x}$ & $\mathrm{x}$ & $\mathrm{x}$ \\
\hline Singapore & $\mathrm{x}$ & $\sqrt{ }$ & $\mathrm{x}$ & $\mathrm{x}$ \\
\hline Thailand & $\sqrt{ }$ & & \\
\hline Vietnam & &
\end{tabular}

Legend

$\sqrt{ }:$ acceded

$\mathrm{x}$ : has not acceded

\section{Overview of the Regional Legal Framework on Piracy}

\section{Regional Cooperation Agreement against Piracy and Armed Robbery}

Cooperation is a key element in preventing, deterring as well as suppressing the act of piracy and armed robbery. This cooperation could be enhanced at multilateral, regional as well as bilateral levels. United Nation General Assembly (UNGA) in one of its resolution stated that international, regional, sub-regional and bilateral cooperation paly significant role in combating piracy, armed robbery and other threats to maritime security. This resolution 63/111 which was passed on $12^{\text {th }}$ February 2009 also showed that the international community are concerned and worried about the escalation on piratical act all over the world ${ }^{44}$. Furthermore, the IMO's Code of Practice for Investigation of Crimes of Piracy and Armed Robbery against ships extends this concern and urged states to create and produce agreements as a tool to cooperate and combat piracy as well as armed robbery against ships ${ }^{45}$.

In line the above mentioned concern, states in Asia, especially in Southeast Asia region adopted the so called Regional Cooperation Agreement against Piracy and Armed Robbery (ReCAAP). This agreement was adopted on $11^{\text {th }}$ November 2004 and came into force on $4^{\text {th }}$ September $2006^{46}$. This initiative was responded positively by the international community. In March 2006 the UNGA passed resolution 60/30 which in principle welcomed the ReCAAP and recommends states to adopt, conclude and implement regional agreements at high risk areas ${ }^{47}$. ReCAAP also served as a guide to the adoption of which serves as a regional measure in western Indian Ocean and Gulf of Aden.

The adoption of ReCAAP went through a long process of negotiations and was the outcome of the multilateral legal frame work which was aimed by the states in the region as a tool to prevent and suppress piracy and armed robbery in Asia (preamble of ReCAAP). The

\footnotetext{
${ }^{44}$ Robin Geiss and Anna Petrig, Piracy and armed robbery at sea: the legal framework for counter-piracy operations in Somalia and the Gulf of Aden (Oxford University Press, 2011)

${ }^{45}$ Ibid

${ }^{46}$ Ibid

${ }^{47}$ Ibid
} 
Drafting of ReCAAP involved 10 members of Association of the Southeast Asian Nations (ASEAN) as well as other six countries from South and East Asia. In accordance to article 18(5) ReCAAP is open to any other states to sign but upon entry into force, however before $4^{\text {th }}$ September 2006 it was only meant for signature for regional states ${ }^{48}$. Currently ReCAAP consists of 19 parties in which two main players in the region namely Indonesia and Malaysia are not members which pose challenge to the development of ReCAAP itself.

\section{Content of ReCAAP}

ReCAAP in its text defined piracy and armed robbery. Its definition is not new to states as it adopted the definition of piracy (article 1 ReCAAP) from article 101 UNCLOS and armed robbery from IMO's Code of Practice for Investigation of armed robbery against ship. It also explained the general provisions in article 3 (1) that states in accordance to national law and international law has to take steps which deemed necessary to: a). Prevent and suppress piracy and armed robbery; b). Arrest pirates or persons committing armed robbery; c). Seize ships or aircraft committing piracy or armed robbery; and d). rescue victims ships as well person of piracy and armed robbery.

ReCAAP also acts as hub for information sharing, cooperation as well as capacity building for member states. Through its Information Sharing Centre (ISP) which is created based on article 4, operates as an information body which shares the collected information to the member states ${ }^{49}$. ISC acts as an international organization which operates with the presence of the government council. The composition of ISC consists of representatives from each contracting parties. ISC also has a secretariat in Singapore which operated for the first time on $29^{\text {th }}$ of November 2006. In addition, article 7 elaborated that ISC serves as the information exchange centre as well as an organization which analyses various reports that are reported by member states. In order to undergo its function ISC requires focal points from each state to ease the communication between ISC and contracting parties ${ }^{50}$. Hence, article 9 regulated that every state has to submit their focal points which will act on behalf of the state to inform and receive information regarding ReCAAP. Through ISC, states are also able to request other states to cooperate in detecting culprits who have committed piracy or armed robbery as stated in article 10 .

ReCAAP also provide extradition measures. According to article 12, member states in accordance with their respective national laws shall cooperate to extradite person who have committed the act of piracy and armed robbery. If the pirates or people are present in one of the member state's territory, upon request by the other contracting states, the state shall cooperate and extradite the perpetrators to the state that has jurisdiction over them ${ }^{51}$. Furthermore, ReCAAP also enable the member states to conduct mutual legal assistance and evidence sharing in accordance with article 13. In these contexts, however, ReCAAP recognizes the presence of the national laws and therefore any prosecution or extradition or mutual legal assistance measures should inconformity with the prevailing national laws ${ }^{52}$.

\footnotetext{
${ }^{48}$ Ibid

${ }^{49}$ Ibid

${ }^{50} \mathrm{Ibid}$

${ }^{51}$ Ibid

${ }^{52}$ Ibid
} 
As a regional measure, ReCAAP does not supersede the enforcement measures of UNCLOS. In line with this view, it does not facilitate member states to seize pirate ship in other state's territorial sea. Although piracy is universal jurisdiction in nature, ReCAAP respects the sovereignty of other states and does not interfere in the national jurisdiction of a state ${ }^{53}$. This assessment is embedded in article 2 (5) of the general provision which in principle explains than no state is entitled to exercise jurisdiction over other state's territorial seas.

Although ReCAAP does not possess great impact in terms of joint maritime enforcement operations, it is believed that ReCAAP has a bright future and will lead the process of eradicating piracy and armed robbery against ships ${ }^{54}$. As mentioned in article 7 (9) that ISC is also entitled to perform other functions which is considered necessary upon the consent of Governing Council. This action could be performed if only consensus is met in accordance with article 4 (6) with the common goal of preventing, suppressing and deterring piracy and armed robbery. This measure might seemed angelic, however, limited enforcement measures as mentioned in article 2 (5) forms a barrier to break through the loopholes of the high seas requirements in $\mathrm{UNCLOS}^{55}$. Nonetheless, For the time being, ReCAAP could be regarded as a tool to foster cooperation and coordination in combating piracy and armed robbery in Asia especially the Southeast Asia region. Therefore, it is not wrong to say that ReCAAP lacks and limited in enforcement measures, but an advantageous tool in terms of coordination and cooperation amongst contracting states in order to prevent and combat piracy and armed robbery against ships in Southeast Asia ${ }^{56}$. The cooperation and coordination between states enhances mutual trust and confidence building which may pave the way for comprehensive cooperation in the future. It might be possible in the future that ReCAAP may have join patrol between states over the Southeast Asian waters as well as more significant enforcement measures in other states territorial waters.

\section{Accession Status of ReCAPP in Southeast Asia}

\begin{tabular}{|l|c|}
\hline Southeast Asian States & ReCAPP \\
\hline Brunei Darussalam & $\sqrt{ }$ \\
\hline Cambodia & $\sqrt{ }$ \\
\hline Indonesia & $\mathrm{x}$ \\
\hline Laos & $\sqrt{ }$ \\
\hline Malaysia & $\mathrm{x}$ \\
\hline Myanmar & $\sqrt{ }$ \\
\hline Philippines & $\sqrt{ }$ \\
\hline Singapore & $\sqrt{ }$ \\
\hline Thailand & $\sqrt{ }$ \\
\hline Vietnam & $\sqrt{ }$ \\
\hline
\end{tabular}

Legend

$\sqrt{ }:$ acceded

$\mathrm{x}$ : has not acceded

\section{Malacca Strait Patrol}

\footnotetext{
${ }^{53}$ Ibid

${ }^{54}$ Ibid

${ }^{55}$ Ibid

${ }^{56}$ Ibid
} 
Another regional effort to suppress piracy especially in Malacca Strait is MALSINDO which was introduced in July 2004. MALSINDO composed of navies from three littoral states in Southeast Asia namely Malaysia, Singapore and Indonesia ${ }^{57}$. Its task is to conduct coordinated patrol within their respective territorial sea around the Strait of Malacca. One of the weaknesses of this patrol is that it does not allow the cross border pursuit over other states territorial sea as it is viewed as interference in other states' sovereignty ${ }^{58}$. Even in hot pursuit, the contracting states are not allowed to enter the territorial waters of other states. Therefore, after the introduction of this measure, there was no immediate reduction in piratical act in the Strait of Malacca.

Significant reduce in piratical attack around the Malacca Strait was reported in 2005. One of the main reasons was the tsunami which affected the northern part of Indonesia (Aceh) and also other coastlines around it. Tsunami resulted in death of huge number of population living in the northern part of Indonesia at that time. Aceh was believed as one of the areas where pirates used to stay. As the result, IMB reported that there was 60 per cent reduction of piracy attacks in 2005 compared to the previous year. Furthermore, even after the recovery of the disaster where the number of people living in Aceh started to grow, the numbers of piracy cases have not been as high as in 2004.

Another reason that could add up to the above mentioned argument is about the political situation of $\mathrm{Aceh}^{59}$. This province was once hugely occupied by Free Aceh Movements (GAM) particularly before the occurrence of tsunami. GAM was in conflict with the national government for more than twenty years. However, after the tsunami, both GAM and the Indonesia government were able to negotiate and decided to stop the conflict ${ }^{60}$. GAM agreed to hand over their weapons, whereas the Indonesian government pull over thousands of their troops from the province.

The reduction of the number of piratical attacks was also influenced by the launching of aerial patrol over the Malacca Straits which is known as the "Eyes in the Sky" (EiS) plan". This plan allows the patrolling aircraft to go over the other states' territorial sea (up to three nautical miles). This measure was enforced as to strengthen the water patrol which has been limited to twelve nautical miles of the respective states.

In 2006, Malacca Straits Patrols (MSP) was formed which consisted of both MALSINDO and EiS. Malacca Strait Patrols Information system (MSP-IS) which used to operate separately, later joined MSP and named as Intelligence Exchange Group (IEG) ${ }^{62}$. This group contributes particularly in exchange of data among the member states. Later, Thailand joined MALSINDO (2008) and EiS (2009) ${ }^{63}$.

\section{ASEAN Measures}

\footnotetext{
${ }^{57}$ Z Raymond, R., 'Piracy and Armed Robbery in the Malacca Strait: A Problem Solved?' in Bruce A Elleman, Andrew Forbes and David Rosenberg (eds), Piracy and maritime crime: Historical and modern case studies (Naval War College Press, 2010)

${ }^{58}$ Ibid

${ }^{59}$ Ibid

${ }^{60}$ Ibid

${ }^{61}$ Ibid

${ }^{62}$ H. Lowen and A. Boedenmuller, 'Straits of Malacca' in Stefan Mair (ed), Piracy and Maritime Security: Regional Characteristics and political, military, legal and economic implications (Stiftung Wissenschaft und Politik, 2011) vol 2,

${ }^{63}$ Ibid
} 
Piracy has also been a concern for ASEAN. Measures to combat piratical attacks have been initiated by some member states of ASEAN ${ }^{64}$. However, maritime security issues including piracy do not affect the entire member of ASEAN. Therefore, to date, there is no anti-piracy measure which involves all members of ASEAN ${ }^{65}$.

Nonetheless ASEAN has been committed to discuss issues related to Maritime Security in their meetings. As the result there are three prominent forums which aim to address Maritime Security, namely: ASEAN Maritime Forum (AMF), ASEAN Regional Forum Inter-Sessional Meeting (ARF-ISM) on Maritime Security, and Maritime Security Expert Working Group $(\mathrm{MSEWG})^{66}$.

The AMF was established in July 2010 which aimed to address issues not limited to Maritime Security such as piracy but also other issues including marine environment, illegal fishing, maritime transportation as well as people smuggling ${ }^{67}$. Moreover, it was also agreed that AMF would facilitate ASEAN connectivity through the establishment of maritime linkages ${ }^{68}$.

The ARF-ISM which was established in July $2008\left(15^{\text {th }}\right.$ meeting of ARF) aimed to facilitate the dialogue of Maritime Security. This dialogue consists of, but not limited to, piracy and armed robbery, smuggling of goods, people smuggling as well as capacity building and cooperation $^{69}$. This meeting has been held annually and the first meeting took place in Indonesia in 2009. On the third meeting which was held in Tokyo, the Work Plan for the group was produced. It identified three main objectives: "a. information/ intelligence exchange and sharing of best practices, including transparency around naval capacity operations; $b$. confidence building measures based on international and legal frameworks, arrangements and cooperation; and c. capacity building of maritime law enforcement agencies in the region"

The MSEWG was initiated by ASEAN Defence Minister Meeting Plus (ADMM Plus) during its inaugural in October 2010. ADMM Plus agreed to look after issues on regional security which includes Maritime Security. MSEWG was aimed to discuss issues, including but not limited to, piracy, search and rescue and illegal trafficking ${ }^{71}$.

Other than the three forums mentioned above, ASEAN has also produced initiatives to address maritime security threats including piracy. Those initiatives among others are: ASEAN Declaration on the Prevention and Control of Transnational Crime, The Hanoi Declaration of 1998, The Bali Concord II 2003, The ASEAN Security Community Plan of Action and Vientiane Action Programme 2004-2010, and ASEAN Political-Security Community Blueprint. In addition the ARF in 2003 has produced the ARF Statement on Cooperation against Piracy and Other Threats to Security ${ }^{72}$. This statement was issued during the tenth ARF meeting in Cambodia.

\footnotetext{
${ }^{64}$ Ibid

${ }^{65}$ Ibid

${ }^{66}$ S. Bateman, 'Solving the "Wiched Problems" of Maritime Security: Are Regional Forums up to the Task?' (2011)

33(1) Contemporary Southeast Asia 1

${ }^{67}$ Ibid

${ }^{68}$ Termsak Chalermpalanupap, “ASEAN and Maritime Security: An Update”, paper presented at Centre for International Law Workshop, "International Maritime Crimes: Legal Issues and Prospects for cooperation in ASEAN", Singapore 17-18 January 2011.

${ }^{69}$ Bateman, above n 66

${ }^{70}$ Chalermpalanupap, above n 68

${ }^{71}$ Bateman, above n 66

${ }^{72}$ Asean Regional Forum Statement on Cooperation Against Piracy And other Threats to Maritime Security. Adopted at 17 June 2003, in Phnom Penh, Cambodia. Online at: <http://www.aseansec.org/14837.htm>
} 


\section{Conclusion: A way forward}

Even though lately the number of piracy cases in Southeast Asia declined, piracy still poses a serious threat in the region as its occurrence affects the international commerce and human safety. The international legal framework such as UNCLOS and SUA Convention seemed to be inadequate to resolve the problem $^{73}$. The narrow definition of piracy in UNCLOS is not able to encompass most of the piratical acts occurring in the region. Piracy occurs in territorial sea whereas UNCLOS punishes acts on the high seas ${ }^{74}$. On the other hand, SUA Convention which was believed as a solution to this problem as it fills the gap left by UNCLOS does not gain popularity in the region. Two important littoral states in the region, Indonesia and Malaysia are not party to SUA 1988 ant its protocol. Furthermore, none of the Southeast Asian states is a party to SUA 2005 and its protocol. Therefore in terms of application, SUA is inapplicable in the region.

The regional forums that address the issue of maritime security which also includes piracy brings hope to the eradication of piracy. Forums such as AMF, ARF-ISM and MSEWG could be used as a tool to gain common understanding and discuss the issue transparently among the states in the region ${ }^{75}$. Many of the forum including these are regarded as 'talk shops', hence, a more technical efforts involving majority of the Southeast Asian states are needed ${ }^{76}$. Having known that the MSP played a significant role in suppression of piracy in the Strait of Malacca, similar effort which involves a larger number of countries in the region could be a part of the solution. Furthermore, the approach of territorial sovereignty which is one of the fundamentals of the non-intervention principle still plays pivotal role in regional states' foreign policy. The application of this approach should be reconsidered as it forms one of the barriers in multilateral cooperation. A cooperative mindset should be developed and promoted, whereas territorial sovereignty will still retain its respect.

Extra regional could also play its role in enhancing the maritime security in the region. Their understanding of the maritime security issues including piracy could help in the capacity building of the people ${ }^{77}$. Moreover, extra regional actors could also be involved in enhancing inter regional initiatives such as ReCAAP. They could join ReCAAP and promulgate initiatives in eradicating piracy. The involvement of Thailand in Malacca Strait Patrol as well as the growing number of member state in ReCAAP showed the possibility of expanding the regional cooperation $^{78}$. Furthermore, this could be the indication that states are aware of the growing importance of cooperation.

Other than ReCAAP, information sharing is also conducted in Malacca and Singapore straits. Furthermore it also involves a number of operational coordination ${ }^{79}$. Activity such as Eyes in the Sky (EiS) is conducted in order to air surveillance the Malacca Strait area. This operation is being conducted Indonesia, Malaysia, Thailand and Singapore. Malacca Straits Sea

\footnotetext{
${ }^{73}$ Erik Barrios, 'Casting a wider net: addressing the maritime piracy problem in Southeast Asia' (2005) 28 BC Int'l \& Comp. L. Rev. 149

${ }^{74}$ Ibid

${ }^{75}$ Bateman, above n 66

${ }^{76}$ Ibid

${ }^{77}$ S. Huang, 'Building Maritime Security in Southeast Asia: Outsiders Not Welcome?' (2008) 61 Naval War College Review 19

${ }^{78}$ Lowen and Boedenmuller, above $\mathrm{n} 62$

${ }^{79}$ ASPI, above $\mathrm{n} 14$
} 
Patrols (MSSP) is also conducted by Indonesia, Malaysia, Thailand and Singapore in order to monitor the sea area of Malacca Strait. EiS and MSSP together with the Intelligence Exchange Group and the Malacca Straits Patrol Information System (MSP-IS) comprises the so called the Malacca Straits Patrol (MSP). MSP has become the basis of the information sharing between states that conduct surveillances and patrols in the Malacca and Singapore straits area ${ }^{80}$.

Building trust and confidence building measure could also be a part of the solution. Information sharing between states would enhance the relations among the states. Furthermore, this could only be done when the political environment in the region is supportive ${ }^{81}$. Arms race and security dilemma should be set aside. Moreover, the expanding of military forces should be done because of arms race or security dilemma, but more to facilitate the need of the corporation.

In relation to Malacca Strait, even though the number of piracy today declined significantly compared to 2004 , the act is believed to still prevail ${ }^{82}$. The current condition could still be improved if Indonesia and Malaysia as coastal states could enhance the economic condition and reduce poverty as well as unemployment. In addition, the current measure such as the MSP is still important and therefore should still be practiced ${ }^{83}$.

The maritime focus of the region should not only concentrate to the Strait of Malacca, but also to the other parts of the region ${ }^{84}$. Having known that after 2004 the number of piracy decreased significantly not only due to tsunami but also by different measures taken by the littoral states, the same practices could also be adapted to other piracy prone areas in the region such as Sulu and Celeb seas ${ }^{85}$.

Measures that are being taken by Southeast Asian states in countering piracy attacks serve as an important lesson to other authorities which are facing the same problem ${ }^{86}$. Southeast Asia is successful in conducting coordinated patrols as well as surveillance in piracy prone areas. Jennings, the Executive Director, ASPI elaborated that Malaysia, Indonesia and Singapore are successful in their counter piracy measures especially on attacks which are conducted around the Malacca and Singapore Straits areas. Furthermore, information sharing between agencies and on shore policing is effectively implemented and enforced. According to Teo, Deputy Director ReCAAP ISC, that piracy should be addressed by the cooperation of various agencies, a single agency would not be sufficient to address the problem. To conduct such cooperation factors such as mutual trust, respect and confidence building among states in the region are needed ${ }^{87}$.

\section{References}

Abhyankar, J., An Overview on Piracy Problems-A Global Update <http://www.sils.org/sminar/1999-piracy-00.htm>

\footnotetext{
${ }^{80}$ Ibid

${ }^{81}$ Bateman, above n 66

${ }^{82}$ Raymond, above n 57

${ }^{83}$ Ibid

${ }^{84}$ Ibid

${ }^{85}$ Ibid

${ }^{86}$ ASPI, above n 14

${ }^{87}$ Ibid
} 
ASPI, 'Special Report: Calming Troubled Waters: Global and Regional Strategies for Countering Piracy ' (Australian Strategic Policy Institute, 2012)

Barrios, Erik, 'Casting a wider net: addressing the maritime piracy problem in Southeast Asia' (2005) 28 BC Int'l \& Comp. L. Rev. 149

Bateman, S., 'Solving the "Wiched Problems" of Maritime Security: Are Regional Forums up to the Task?' (2011) 33(1) Contemporary Southeast Asia 1

Geiss, Robin and Anna Petrig, Piracy and armed robbery at sea: the legal framework for counter-piracy operations in Somalia and the Gulf of Aden (Oxford University Press, 2011)

Harrelson, J., 'Blackbeard meets blackwater: An analysis of international conventions that address piracy and the use of private security companies to protect the shipping industry' (2010) 25 Am. U. Int'I L. Rev. 313

Huang, S., 'Building Maritime Security in Southeast Asia: Outsiders Not Welcome?' (2008) 61 Naval War College Review 19

Johnson, D. , E. Pladder and M Valencia, J., 'Introduction: Research on Southeast Asian Piracy' in D. Johnson, E. Pladdet and M Valencia, J. (eds), Piracy in Southeast Asia: Status, Issues, and Responses (ISEAS, 2005)

Kaye, S., 'The International Legal Framework for Piracy' in A. Forbes (ed), Australia's Response to Piracy: A Legal Perspective (National Library of Australia, 2011) vol 31, 10

Lowen, H. and A. Boedenmuller, 'Straits of Malacca' in Stefan Mair (ed), Piracy and Maritime Security: Regional Characteristics and political, military, legal and economic implications (Stiftung Wissenschaft und Politik, 2011) vol 2,

Mukundan, P., 'The Scourage of Piracy in Southeast asia: Can Any Improvements be Expected in the Near Future?' in D. Pladder Johnson, E. Valencia, M, J. (ed), Piracy in Southeast Asia: Status, Issues, and Responses (ISEAS, 2005)

Raymond, Z, R., 'Piracy and Armed Robbery in the Malacca Strait: A Problem Solved?' in Bruce A Elleman, Andrew Forbes and David Rosenberg (eds), Piracy and maritime crime: Historical and modern case studies (Naval War College Press, 2010)

Shie, T., 'Maritime Piracy in Southeast Asia: The Evolution and Progress of Intra-ASEAN Cooperation' in G. Gerard and O. Webb (eds), Piracy, Maritime Terrorism and Securing the Malacca Straits (ISEAS Publishibg, 22 
Today, Safer Waters: Global Piracy Menance on the Wane (27 March 2014) $<$ http://www.todayonline.com/sites/default/files/manualassets/pirates 2014/index.html>

Young, AJ, 'Roots of Contemporary Maritime Piracy in Southeast Asia' in D. Johnson and M. Valencia (eds), Piracy in Southeast Asia: Status, Issues, and Responses (ISEAS Publications, 2005) 33

Zou, K., 'Enforcing the Law of Piracy in the South China Sea' (2000) 31 Journal of Maritime Law and Commerce 